\title{
Perbandingan Laju Pertumbuhan dan Produksi Eucheuma Denticulatum Yang Dipelihara Dengan Long Net dan Wall Net
}

\section{[Comparison of Growth Rate and Production Eucheuma denticulatum Cultivated in Long Net and Wall Net]}

\author{
$\operatorname{Mardin}^{1}$, Abdul Rahman ${ }^{1 *}$, Ma'ruf Kasim² \\ ${ }^{1}$ Program Studi Budidaya Perairan, Fakultas Perikanan dan Ilmu Kelautan, Universitas Halu Oleo \\ ${ }^{2}$ Program Studi Manajemen Sumberdaya Perairan, Fakultas Perikanan dan Ilmu Kelautan, Universitas Halu Oleo \\ JL. HAE Mokodompit Kampus Bumi Tridharma Anduonohu Kendari, Indonesia, 93232 \\ *Email korespondensi: abdulrahman@uho.ac.id
}

\begin{abstract}
ABSTRAK
Eucheuma denticulatum merupakan salah satu jenis rumput laut yang ikut andil dalam meningkatkan produksi rumput laut di Indonesia. Berkaitan dengan proses budidayanya, penelitian ini bertujuan untuk mengetahui perbandingan laju pertumbuhan dan produksi $E$. denticulatum yang dipelihara dengan long net dan wall net, demikian hubungannya dengan parameter fisikakimia perairan. Penelitin ini dilaksanakan pada Oktober-Desember 2019 di Perairan Pantai Lakeba Kota Baubau Sulawesi Tenggara, menggunakan rancangan acak lengkap (RAL) dengan alat analisis uji-t (Independent sampel t-test) dan regresi linear berganda. Hasil penelitian diperoleh laju pertumbuhan spesifik (LPS) masing-masing sebesar 2,98\%.hari ${ }^{-1}$ pada long net dan sebesar 2,58\%.hari ${ }^{-1}$ pada wall net, sedangkan produksi rumput laut basah masing-masing sebesar 769,06 g.m ${ }^{-2}$ dan sebesar 643,44 g.m ${ }^{-2}$. Posisi kedalaman tanam, keterlindungan, dan kestabilan rumpun rumput laut menjadi pembeda hasil LPS dan produksi $E$. denticulatum pada kedua alat tersebut. Parameter kualitas air yang mempengaruhi pertumbuhan $E$. denticulatum yaitu suhu, salinitas, kecepatan arus, $\mathrm{pH}$, nitrat, dan fosfat. Wall net memiliki kelebihan dibanding long net terutama pada kondisi perairan yang agak terbuka dan keberadaan hama.
\end{abstract}

Kata Kunci: long net, wall net, produksi Eucheuma denticulatum, pantai lakeba.

\section{ABSTRACT}

Eucheuma denticulatum is one type of seaweed that contributes to increasing seaweed production in Indonesia. With regard to the cultivation process, this study aims to determine the ratio of growth rate and production of $E$. denticulatum reared with long net and wall net, as well as its relationship with water physico-chemical parameters. This research was conducted in October-December 2019 in Lakeba Coastal Waters, Baubau City, Southeast Sulawesi, using a completely randomized design (CRD) with t-test analysis (Independent sample t-test) and multiple linear regression. The results showed that the maintenance of $E$. denticulatum with a long net and a wall net resulted in a specific growth rate (LPS) of $2.98 \%$.day- 1 and $2.58 \%$.day-1, respectively, while the production of seaweed The resulting wet value was also 769.06 gm-2 and 643.44 gm-2, respectively. The position of planting depth, protection, and stability of seaweed clump were the differences between LPS results and $E$. denticulatum production in the two tools. Water quality parameters that affect the growth of E. denticulatum in Lakeba Coastal Waters are temperature, salinity, current velocity, $\mathrm{pH}$, nitrate, and phosphate. Both of these seaweed cultivation tools have the potential to develop seaweed cultivation in coastal waters. Wall nets have advantages over long nets, especially in relatively open water conditions and the presence of pests.

Keywords: long net, wall net, production of Eucheuma denticulatum, Lakeba waters

\section{PENDAHULUAN}

Eucheuma denticulatum atau lebih dikenal dengan nama Eucheuma spinosum adalah salah satu jenis rumput laut yang ikut andil dalam meningkatkan hasil produksi rumput laut di Indonesia. E. spinosum merupakan salah satu alternatif dalam rangka upaya meningkatkan pendapatan para petani ataupun nelayan serta dalam pemanfaatan lahan di wilayah pesisir pantai. E. spinosum mempunyai nilai ekonomis penting karena mengandung karagenan yang banyak dimanfaatkan dalam industri makanan, kosmetik, farmasi serta industri lainnya seperti tekstil, kertas, fotografi, pasta dan pengalengan ikan (Abdan et al. 2013).

Peningkatan produksi rumput laut sangat didukung oleh penerapan teknik atau metode budidaya yang tepat, penentuan metode budidaya yang kurang tepat akan berakibat pada produksi dan kualitas rumput laut yang kurang maksimal. Selama ini metode budidaya rumput laut dilakukan dengan metode rakit dan longline. Selain itu penggunaan metode tersebut di perairan terbuka sangat rentan dengan kegagalan produksi yang disebabkan oleh keterbatasan dalam pengontrolan dan faktor 
lingkungan, salah satunya adalah serangan ikan herbivora pemakan rumput laut seperti beronang, penyu, abalon, dan bulu babi (Lakhsmi, 2015)

Pertumbuhan rumput laut sangat dipengaruhi oleh kondisi lingkungan perairan tempat pembudidayaan dilakukan. Parenrengi et al. (2008) dan Pongmasak et al. (2009) merekomendasikan bahwa setiap sentra budidaya rumput laut memiliki kalender musim yang dapat dijadikan acuan dalam menentukan kapan mulai penanaman dan spesies mana yang sesuai untuk dibudidayakan. Pertumbuhan rumput laut terjadi karena rumput laut melakukan proses respirasi dan fotosintesis. Pertumbuhan rumput laut sangat dipengaruhi oleh dua faktor yaitu faktor internal dan faktor eksternal. Faktor internal yang berpengaruh antara lain jenis, galur/strain, bagian thallus dan umur bibit. Sedangkan faktor eksternal yang berpengaruh antara lain keadaan fisik dan kimiawi perairan.

Saat ini telah dikembangkan metode budidaya yang dapat memproteksi rumput laut dari organisme herbivora yaitu metode rakit jaring apung. Metode rakit jaring apung merupakan metode budidaya dengan cara menyimpan rumput laut di dalamnya tanpa mengikatnya dengan demikian dapat terlindung dari organisme herbivora (Kasim, 2016).

Keberhasilan budidaya rumput laut yang cocok di perairan pantai selain membutuhkan lokasi yang cocok dan kualitas bibit yang baik juga dipengaruhi oleh penerapan teknik budidaya yang tepat. Long net dan wall net merupakan teknik inovasi alat budidaya rumput laut yang didesain dari bahan jaring, long net hampir mirip dengan metode longline namun long net dilengkapi dengan jaring memanjang yang membungkus rumput laut seperti kantung panjang. Kelebihan dari media ini yaitu dapat mengurangi serangan hama yang akan mengganggu pertumbuhan rumput laut. Sedangkan wall net juga merupakan alat budidaya rumput laut berbentuk persegi yang terbuat dari pipa paralon ukuran 2 inci dilengkapi dengan dinding jaring namun tidak terproteksi. Berdasarkan uraian tersebut diperlukan adanya informasi dari penelitian yang bertujuan membandingkan besaran laju pertumbuhan dan produksi $E$. denticulatum berikut hubungannya dengan kualitas air pada long net dan wall net di perairan.

\section{BAHAN DAN METODE}

Penelitian ini dilaksanakan selama 42 hari dari bulan Agustus sampai November 2019, yang bertempat di Perairan Pantai Lakeba Kota Bau-bau, Provinsi Sulawesi Tenggara. Lokasi penelitian berada pada posisi $05^{\circ} 29^{\prime} 16,47^{\prime \prime} \quad$ LS dan $122^{\circ} 33^{\prime} 44,35^{\prime \prime} \quad$ BT (Gambar 1). Penelitian dilaksanakan di perairan pantai Lakeba, Kota Bau-bau, Sulawesi Tenggara yang berjarak 75 sampai 100 meter dari garis pantai. Penentuan lokasi ini mengacu sebagaimana yang disarankan Bolqiah, dkk. (2018) yaitu, bebas dari pencemaran limbah masyarakat sehingga dapat menunjang pertumbuhan rumput laut serta lokasi dekat dengan usaha budidaya rumput laut yang dilakukan masyarakat pesisir dan mudah dijangkau.

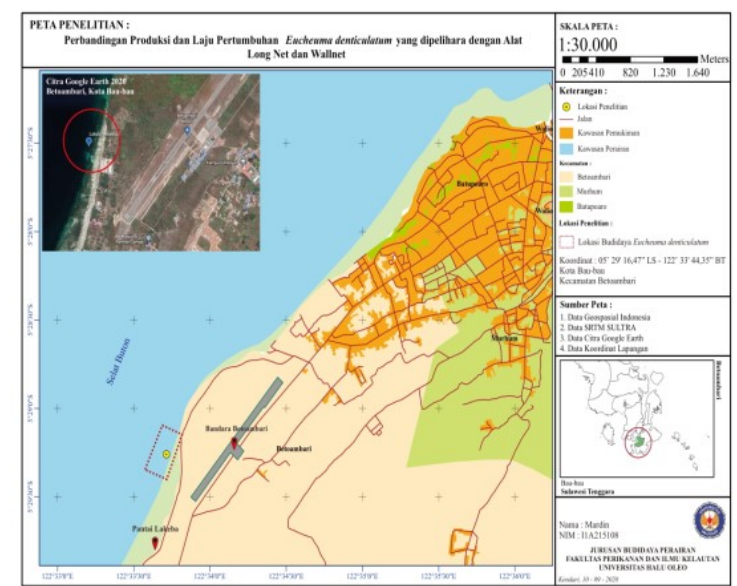

Gambar 1. Peta lokasi penelitian di Perairan Pantai Lakeba Kota Bau-bau Sulawesi Tenggara.

\section{Wadah Budidaya}

Wadah budidaya yang digunakan dalam penelitian berupa jaring berbentuk long net dan wall net. Kedua alat/wadah budidaya rumput laut tersebut terbuat dari bahan jaring multifilamen dengan meshsize $2,5 \mathrm{~cm}$. Jaring long net berbentuk seperti kantung panjang yang terbuka sisi atasnya sedangkan jaring wall net berbentuk persegi dan terpasang secara vertikal di perairan. Ukuran wadah masingmasing berukuran lebar $80 \mathrm{~cm}$ dan panjang jaring $4 \mathrm{~m}$, dimana pada sisi panjang kedua alat tersebut dibuat rangka pembatas dengan jarak setiap 1 meter sehingga setiap wadah jaring terbagi menjadi empat bagian. Setiap petak jaring memiliki ukuran luas yang sama yaitu berukuran $80 \mathrm{~cm}$ x $100 \mathrm{~cm}$. Rangka jaring 
Media Akuatika : Jurnal Ilmiah Jurusan Budidaya Perairan. 2021. 6(4): 192-203.

terbuat dari pipa paralon diameter 2 inch dan besi beton. Masing-masing alat dipasang di lokasi perairan yang telah dipilih setelah semua bibit rumput laut telah diikat pada masingmasing jaring. Ada pun bentuk kedua wadah alat budidaya rumput laut masing masing terlihat pada Gambar 2 dan Gambar 3.

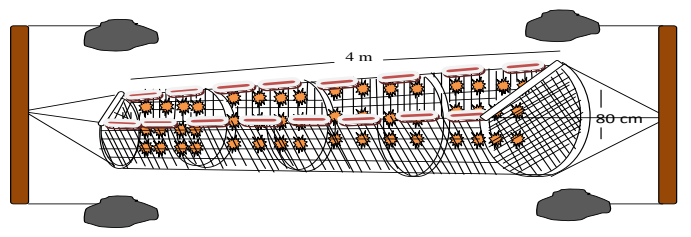

Gambar 2. Long net

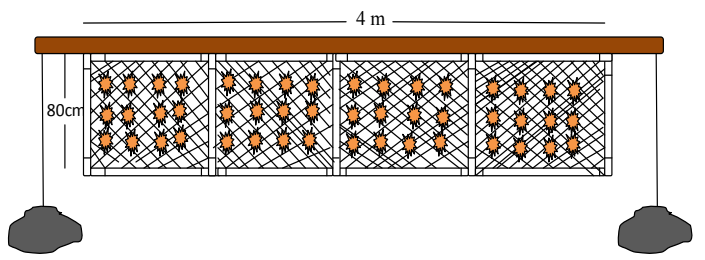

Gambar 3. Wall net

\section{Penanaman/Pengikatan Bibit}

Bibit yang disiapkan merupakan jenis rumput laut $E$. denticulatum yang diperoleh dari petani rumput laut setempat. Rumput laut $E$. denticulatum ditimbang masing-masing dengan berat $20 \mathrm{~g}$ tiap rumpun. Bibit rumput laut ditanam/diikat pada long net dan wall net dengan jarak 20x20 cm, sehingga dalam setiap petak jaring terdapat 12 ikat atau sebanyak 48 ikat rumpun rumput laut jenis E. denticuatum, baik pada long net maupun wall net.

\section{Pemeliharaan Rumput Laut}

Rumput laut $E$. denticulatum yang telah ditanam dan ditempatkan di lokasi perairan, dilakukan upaya pemeliharaan rumput laut budidaya dengan rutin memantau dan membersihkannya. Pemantauan dilaksanakan setiap minggu dalam periode pemeliharaan yang berlangsung selama 42 hari. Pengamatan yang dilakukan meliputi penimbangan pertumbuhan bobot rumput laut $E$. denticulatum, pembersihan dari tanaman lain seperti epifit dan kotoran yang menempel pada tanaman dan pemeriksaan kondisi alat budidaya.

\section{Rancangan Penelitian}

Penelitian didesain dengan rancangan acak lengkap (RAL). Perlakuan terdiri atas metode pemeliharaan long net dan metode pemeliharaan wall net. Masing-masing metode alat pemeliharaan rumput laut terdiri atas empat petak luas yang sama sebagai ulangan.

\section{Variabel yang Diamati}

\section{Laju Pertumbuhan Spesifik (LPS)}

Untuk menghitung LPS digunakan rumus persamaan Luhan and Sollesta (2010); Bolqiah (2018)

$$
\text { LPS }=\frac{(\ln W t-\ln W 0)}{\mathrm{t}} \times 100 \%
$$

Dimana : LPS $=$ Laju pertumbuhan spesifik $(\% /$ hari $) ; \ln \mathrm{Wt}=$ logaritma naturak bobot akhir rumput laut; $\ln \mathrm{Wo}=$ logaritma natural bobot awal rumput laut; $\mathrm{t}=$ jumlah hari pemeliharaan (hari).

\section{Produksi Rumput Laut}

Produksi basah rumput laut penelitian ini dihitung dengan rumus relatif modifikasi Abdan, dkk. (2013) sebagai berikut :

$$
\mathrm{P}=\frac{\sum_{\mathrm{i}=1}^{\mathrm{n}=12}(\mathrm{Wt}-\mathrm{W} 0)}{\mathrm{A}}
$$

Dimana : $\mathrm{P}=$ Produksi rumput laut $\left(\mathrm{g} \cdot \mathrm{m}^{-2}\right) ; \mathrm{Wt}=$ Bobot akhir (g); W0 = Bobot awal (g); A = Luas area budidaya rumput laut $\left(\mathrm{m}^{2}\right) ; \mathrm{i}=$ $1,2,3, \ldots \ldots \ldots \ldots . ., \mathrm{n}=12$ (jumlah rumpun).

\section{Pengukuran Kualitas Kimia-Fisika}

Pengukuran parameter kualitas air dilakukan pada saat pengamatan pertumbuhan dan produksi bobot rumput laut sebanyak 7 kali dengan rentang waktu 7 hari. Parameter kualitas air yang diukur adalah suhu, kecerahan dan kecepatan arus, dan salinitas dilakukan secara in situ, sedangkan nitrat dan fosfat dianalisa di Laboratorium Unit Produktivitas dan Lingkungan Perairan Fakultas Perikanan dan Ilmu Kelautan Universitas Halu Oleo.

\section{Analisis Hubungan Laju Pertumbuhan Spesifik Rumput Laut $E$. denticulatum dan Parameter Kualitas Air.}

Untuk mengetahui hubungan antara laju pertumbuhan rumput laut dengan beberapa parameter kualitas air digunakan metode analisis multivariate. Ada pun model hubungan laju pertumbuhan rumput laut dengan multivariabel kualitas air di Perairan Pantai Lakeba mengikuti model persamaan regresi linear berganda (Suyono, 2012).

$$
\mathrm{Y}=\mathrm{a}+\mathrm{b} 1 \mathrm{X} 1+\mathrm{b} 2 \mathrm{X} 2+\mathrm{b} 3 \mathrm{X} 3 \ldots . . .+\mathrm{bnXn}
$$

Dimana: $\mathrm{Y}=$ laju pertumbuhan rumput laut; $\mathrm{a}=$ Koefisien intersep; $\mathrm{b}=$ Koefisien regresi; $\mathrm{X}=$ 
Media Akuatika : Jurnal Ilmiah Jurusan Budidaya Perairan. 2021. 6(4): 192-203.

Peubah bebas (variabel kualitas air lokasi penelitian) meliputi, suhu(X1), salinitas (X2), kecepatan arus (X3), $\mathrm{pH}$ (X4), nitrat (X5) dan fosfat (X6)

\section{Analisis Data}

Untuk mengetahui pengaruh antara perlakuan terhadap variabel yang akan diamati maka dianalisis dengan uji-t (Independent sampelt-test). Untuk memudahkan, digunakan software statistika SPSS versi 16.

\section{HASIL}

\section{Laju Pertumbuhan Spesifik (LPS)}

Hasil rata-rata perhitungan laju pertubuhan spesifik (LPS) rumput laut $E$. denticulatum dengan menggunakan long net dan wall net selama penelitian tersaji pada Gambar 4. Demikian halnya terhadap kondisi perubahan LPS rumput laut E. denticulatum pada setiap waktu (minggu) selama pemeliharaan rumput laut tersebut disajikan dalam Gambar 5.

Gambar 4 memperlihatkan LPS rumput laut pada wadah pemeliharaan long net sebesar $2,98 \%$ hari $^{-1}$ sedangkan pada wall net sebesar 2,58\% hari $^{-1}$. Berdasarkan analisis perbandingan dengan uji t diperoleh informasi bahwa kedua jenis wadah yang dicobakan menghasilkan LPS rumput laut $E$. denticulatum yang berbeda nyata. Selanjutnya pada Gambar 5 memperlihatkan perubahan LPS pada masingmasing wadah pemeliharaan selama penelitian. Gambar tersebut terlihat perubahan LPS yang semakin menurun dengan bertambahnya waktu pemeliharaan, baik pada wadah long net maupun wall net. Penurunan LPS setiap minggu yang terjadi pada wadah wall net lebih besar dibandingkan dengan wadah long net.

\section{Produksi Rumput Laut}

Hasil rata-rata produksi rumput laut $(E$. denticulatum) yang dibudidaya dengan menggunakan metode long net dan wall net selama penelitian, tersaji pada Gambar 6. Data produksi rumput laut $E$. denticulatum pada kedua alat tersebut terlihat besarannya berbeda.

Hasil penelitian pada Gambar 6 diperoleh produksi basah rumput laut $E$. denticulatum pada wadah pemeliharaan longnet sebesar 769,06 g. $\mathrm{m}^{-2}$ dan wallnet sebesar 643,44 g.m $\mathrm{m}^{-2}$. Hasil uji perbandingan (uji t) diperoleh informasi bahwa perbandingan kedua wadah budidaya rumput laut (longnet dan wallnet) berbeda signifikan terhadap produksi rumput laut E. denticulatum pada taraf kepercayaan $95 \%$.

\section{Kualitas Air}

Parameter yang diamati selama penelitian meliputi: suhu, salinitas, kecepatan arus, nitrat $\left(\mathrm{NO}_{3}\right)$, dan fosfat $\left(\mathrm{PO}_{4}\right)$ diamati setiap 7 hari sekali selama 42 hari. Kisaran hasil pengukuran kualitas air perairan lokasi selama penelitian dan pembanding yang digunakan, sebagaimana pada Tabel 1.

\section{Analisis Hubungan Pertumbuhan Rumput Laut $E$. denticulatum dan Kualitas Air}

Hasil Tabel 2 memperlihatkan bahwa pada alat budidaya long net dan alat wall net terdapat hubungan secara signifikan dengan parameter kualitas air Perairan Lakeba. Tidak ada perbedaan jenis parameter yang berpengaruh signifikan terhadap LPS rumput laut pada alat long net maupun wall net. Jenis parameter yang berpengaruh signifikan tersebut adalah suhu perairan (X1), kecepatan arus (X2), $\mathrm{pH}$ (X4), konsentrasi nitrat (X5), dan konsentrasi posfat perairan (X6), sedangkan yang tidak berpengaruh signifikan adalah parameter salinitas perairan (X3).

Berdasarkan Tabel 2 dapat disusun Persamaan Model hubungan antara laju pertumbuhan rumput laut $E$. denticulatum pada masing-masing alat budidaya long net dan alat wall net dengan parameter kualitas air Perairan Pantai Lakeba. Persamaan model hubungan tersebut untuk alat long net dan alat wall net masing-masing secara berurut pada Persamaan Y1 dan Persamaan Y.

$$
\begin{aligned}
\mathrm{Y} 1= & 62,18+20,27 \mathrm{X} 2+1,75 \times 4+44,06 \mathrm{X} 5- \\
& 2,61 \mathrm{X} 1-105,25 \mathrm{X} 6 \\
\mathrm{Y} 2= & 58,98+1,38 \mathrm{X}+68,67 \mathrm{X} 5+33,23 \mathrm{X} 6- \\
& 2,31 \mathrm{X} 1-37,39 \mathrm{X} 2
\end{aligned}
$$

Dimana : Y1 = LPS rumput laut $E$. denticulatum pada alat long net; Y2 $=$ LPS rumput laut $E$. denticulatum pada wall net; $\mathrm{X} 1$ = variabel suhu perairan; $\mathrm{X} 2=$ variabel kecepatan arus perairan; $\mathrm{X} 4$ $=$ variabel $\mathrm{pH}$ perairan; $\mathrm{X} 5=$ variabel konsentrasi nitrat perairan; X6 = variabel konsentrasi posfat perairan

Persamaan Y1 memperlihatkan model hubungan LPS rumput laut berhubungan signifikan positif dengan parameter kecepatan arus (X2), $\mathrm{pH}(\mathrm{X} 4)$, dan parameter konsentrasi nitrat (X5), sementara parameter suhu (X1) dan 
parameter konsentrasi posfat (X6) berhubungan signifikan negatif dengan LPS rumput laut $E$. denticulatum. Demikian halnya persamaan Y2 memperlihatkan hubungan signifikan positif LPS rumput laut uji dengan paramater $\mathrm{pH}$ (X4), konsentrasi Nitrat (X5) dan konsentrasi posfat (X6), namun berhubuhan signifikan negatif dengan parameter suhu (X1) dan parameter kecepatan arus (X2).

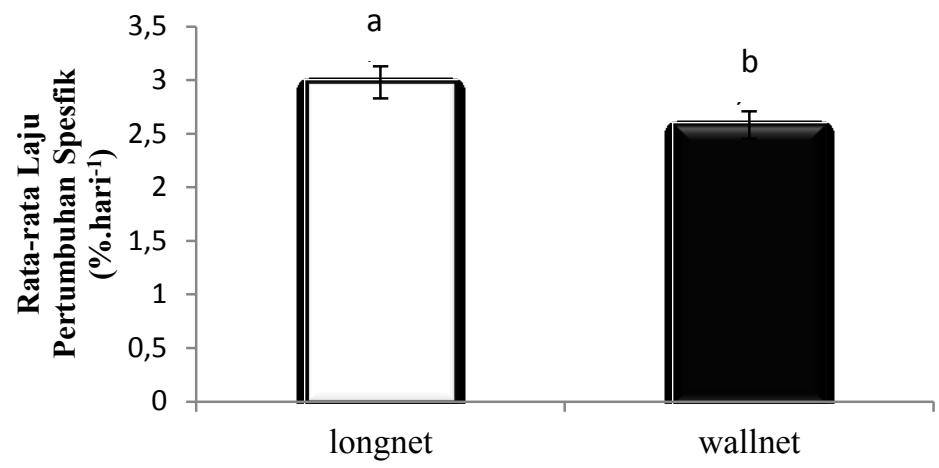

Gambar 4. Rata-rata laju pertubuhan spesifik rumput laut (E. denticulatum) yang dipelihara dengan long net dan wall net. ${ }^{\mathrm{a}, \mathrm{b}}$ superscript yang berbeda menunjukkan perbedaan yang signifikan pada taraf $\alpha=0,05$.

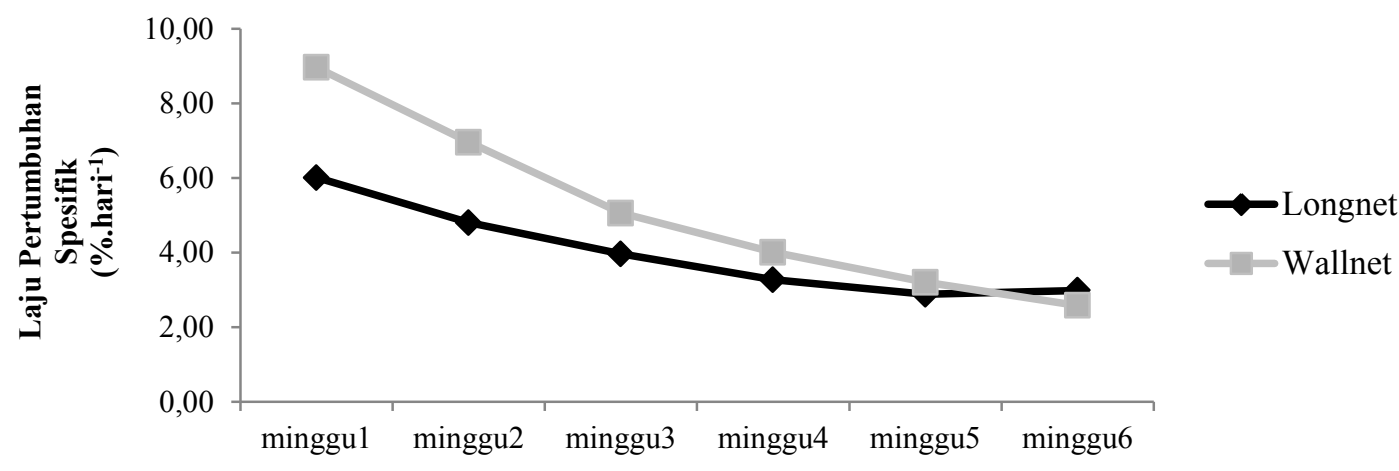

Gambar 5. Grafik laju pertumbuhan spesifik E. Denticulatum yang dipelihara dengan long net dan wall net.

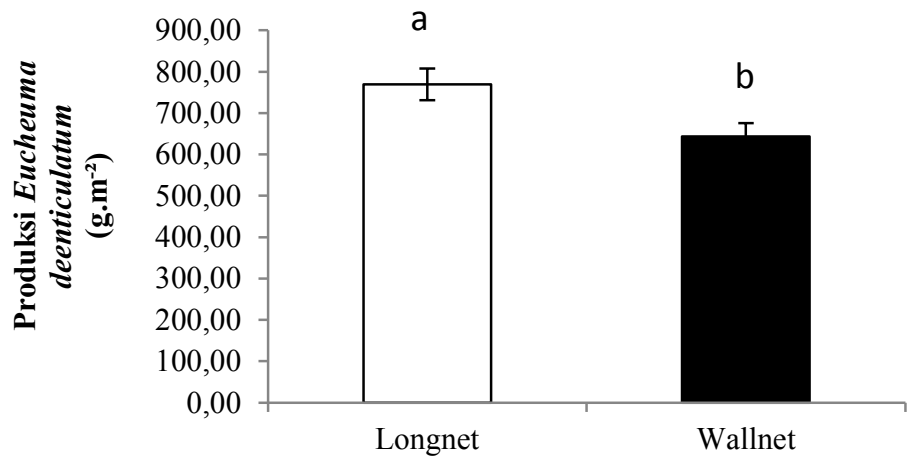

Gambar 6. Rata-rata produksi rumput laut (E. denticulatum) yang dipelihara dengan long net dan wall net. ${ }^{\mathrm{a}, \mathrm{b}}$ superscript yang berbeda menunjukkan perbedaan yang signifikan pada taraf $\alpha=0,05$. 
Media Akuatika : Jurnal Ilmiah Jurusan Budidaya Perairan. 2021. 6(4): 192-203.

Tabel 1. Hasil pengukuran kualitas air selama penelitian

\begin{tabular}{lccl}
\hline Parameter & Satuan & Kisaran & \multicolumn{1}{c}{ Pembanding } \\
\hline $\mathrm{pH}$ & - & $7.30-7.81$ & $7,5-8$ (Anton, 2017) \\
Salinitas & $\mathrm{ppt}$ & $34-35$ & $33-35$ (Anggadiredja, 2006) \\
Suhu & ${ }^{\circ} \mathrm{C}$ & $28-30$ & $26-30$ (Hilmi,2013) \\
Kecerahan & $\%$ & 100 & 100 (Preisy, 2016) \\
Kecepatan Arus & $\mathrm{m} / \mathrm{s}$ & $0,119-0,222$ & $0,1-0,3$ (Ambas, 2006) \\
Kedalaman & $\mathrm{M}$ & $2-7$ & $10-50$ (Noor, 2006) \\
Nitrat $\left(\mathrm{NO}_{3}\right)$ & $\mathrm{mg} / 1$ & $0.045-0.09$ & 0,084 (Armita, 2011) \\
Phosfat $\left(\mathrm{PO}_{4}\right)$ & $\mathrm{mg} / 1$ & $0.02-0.04$ & $0,032-0,096$ (Blink, 2004) \\
\hline
\end{tabular}

Tabel 2. Hasil analisis regresi linear berganda hubungan laju pertumbuhan spesifik rumput laut $E$. denticulatum dengan parameter kualitas air Perairan Pantai Lakeba pada alat longnet dan wallnet

\begin{tabular}{|c|c|c|c|c|c|c|c|}
\hline \multirow{3}{*}{$\begin{array}{l}\text { Variabel } \\
\text { Terikat }\end{array}$} & \multicolumn{7}{|c|}{ Variabel Bebas } \\
\hline & \multicolumn{6}{|c|}{ Masuk dalam model (signifikan) } & \multirow{2}{*}{$\begin{array}{l}\text { Tidak masuk dalam } \\
\text { model (non- } \\
\text { signifikan) }\end{array}$} \\
\hline & Constant & $\begin{array}{l}\text { Suhu } \\
\text { (X1) }\end{array}$ & $\begin{array}{l}\text { Kec. Arus } \\
\text { (X2) }\end{array}$ & $\begin{array}{l}\mathrm{pH} \\
(\mathrm{X} 4)\end{array}$ & $\begin{array}{l}\text { Nitrat } \\
\text { (X5) }\end{array}$ & $\begin{array}{l}\text { Fosfat } \\
\text { (X6) }\end{array}$ & \\
\hline $\begin{array}{l}\text { LPS } \\
\text { rumput } \\
\text { laut pada } \\
\text { Longnet }\end{array}$ & 62,18 & $-2,61$ & 20,27 & 1,75 & 44,06 & $-105,25$ & Salinitas (X3) \\
\hline $\begin{array}{l}\text { LPS } \\
\text { rumput } \\
\text { laut pada } \\
\text { Wallnet }\end{array}$ & 58,98 & $-2,31$ & $-37,39$ & 1,38 & 68,67 & 33,23 & Salinitas (X3) \\
\hline
\end{tabular}

\section{PEMBAHASAN}

\section{Laju Pertumbuhan Spesifik}

Rata-rata laju pertumbuhan spesifik (LPS) E. denticulatum pada Gambar 4 diperoleh hasil yang lebih baik pada metode long net yang berkisar 2,98\% .hari $^{-1}$ dibanding dengan LPS pada wall net yang hanya berkisar $2,58 \%$. hari $^{-1}$. Perbedaan hasil tersebut dapat diakibatkan oleh perbedaan posisi tanam rumput laut dari permukaan perairan pada kedua alat tersebut. Rumpun rumput laut peliharaan yang menerima intensitas radiasi matahari yang tinggi akan relatif memiliki laju pertumbuhan harian yang lebih tinggi pula, demikian sebaliknya. Hal ini sesuai dengan pernyataan Julizar (2018), bahwa intensitas cahaya juga berkaitan langsung dengan produktivitas primer suatu perairan, semakin tinggi intensitas suatu cahaya maka semakin tinggi pula produktivitas primer pada suatu batasan tertentu.

Pemeliharaan E. denticulatum pada long net sistem penanamannya relatif horizontal di permukaan perairan pada kisaran kedalaman
15-30 cm, mengikuti lekukan jaring berbentuk setengah lingkaran yang memanjang di permukaan perairan. Sistem pemeliharaan rumput laut pada long net praktis relatif tidak ada perbedaan penerimaan radiasi matahari untuk masing-masing rumpun rumput laut peliharaan dalam pembangkitan dan berlangsungnya proses fotosintesis. Lain halnya pemeliharaan rumput laut pada wall net, dimana rumpun rumput laut lebih banyak ditanam secara vertikal pada jaring yang dipasang secara vertikal yang memanjang. Sistem pemeliharaan rumput laut pada wall net mengakibatkan penerimaan intensitas radiasi matahari yang berbeda pada setiap perbedaan kedalaman pemeliharaan rumpun rumput laut (kisaran kedalaman penanaman 15-80 cm). Rumpun rumput laut yang ditanam pada baris permukaan perairan menerima intensitas radiasi matahari lebih tinggi dibanding dengan yang berada di baris lapisan bawah. Kondisi demikian, rumpun rumput laut pada baris permukaan perairan tentu memiliki pertumbuhan yang relatif lebih baik dibanding dengan yang ditanam pada baris lapisan di 
bawahnya, sehingga akumulasi dan rata-rata LPS rumput laut yang ditanam pada wall net ini lebih rendah dibanding dengan LPS rumput laut pada long net. Hal ini sesuai dengan pernyataan Sapitri et al. (2016) bahwa fotosintesis akan bertambah sejalan dengan peningkatan intensitas cahaya pada suatu nilai optimum tertentu (cahaya saturasi). Kemudian didukung oleh pernyataan Insan $d k k$. (2013) bahwa perbedaan posisi tanam dan modifikasi sistem jaring, mempengaruhi intensitas cahaya dan unsur hara yang diterima rumput laut untuk pertumbuhannya akan menghasilkan produksi yang berbeda pula.

Selain menyebabkan LPS rumput laut akhir menjadi lebih rendah, urgensi keterlindungan ini menjadi penyebab perubahan LPS rumput laut secara mingguan selama pemeliharaan juga berbeda. Gambar 5 memperlihatkan penurunan LPS E. denticulatum per minggu menurun tajam pada wall net dibanding dengan penurunan LPS $E$. denticulatum pada long net. LPS $E$. denticulatum pada wall net pada mingguminggu awal pemeliharaan jauh lebih tinggi dibanding dengan LPS $E$. denticulatum pada long net, bahkan hanya pada minggu terakhir pemeliharaan LPS E. denticulatum pada long net lebih tinggi dan signifikan dibanding dengan LPS E. denticulatum akhir pada wall net. Hasil pengamatan di lapangan bahwa relatif banyak organisme-organisme predator yang ditemukan keberadaannya di sekitar rumpun $E$. denticulatum yang dipelihara dengan wall net. Sebaliknya pada long net, E. denticulatum yang dipelihara dengan long net relatif aman dari gangguan hama. Insan $d k k$., (2013) menyatakan bahwa keuntungan dari modifikasi sistem jaring adalah bibit rumput laut tidak mudah hilang, baik untuk perairan yang berdasar pasir dan karang, serta tidak mudah dimakan ikan dan herbivor.

Perbedaan sistem keterlindungan selainnya adalah kestabilan rumpun rumput laut selama pemeliharaan pada kedua alat budidaya tersebut. Rumpun rumput laut yang stabil dalam medium selama pemeliharaan akan memberikan LPS rumput laut yang lebih stabil pula. Alat long net yang memiliki rangka memanjang dan berbentuk setengah lingkaran menghadap ke atas, dapat memberikan perlindungan kekakuan dari pengaruh goyangan rumpun rumput laut yang berlebih akibat pengaruh ombak dan atau arus. Berbeda dengan alat wall net, yang pemasangan jaringnya secara vertikal, dapat menyebabkan goyangan berlebih pada E. denticulatum yang ditanam secara baris vertikal. Goyangan rumpun $E$. denticulatum yang berlebih dapat menyebabkan patahnya batang dan percabangan rumpun $E$. denticulatum tersebut. Kondisi demikian diduga menjadi penyebab lebih tajamnya penurunan LPS E. denticulatum per minggu pada wall net dibanding dengan long net. Hal ini sesuai pendapat Insan $d k k$., (2013) bahwa budidaya menggunakan jaring dapat mencegah hilangnya rumput laut karena terbawa arus. Jaring waring, tabung dan tubuler memiliki lubang jaring yang lebih kecil dari ukuran talus rumput laut sehingga talus rumput laut dapat bergerak bebas mengikuti gerakan arus air.

Pertumbuhan harian rumput laut dengan kisaran nilai tersebut dikatakan cukup baik untuk pertumbuhan harian pada rumput laut. Hal ini sesuai dengan pernyataan Ariyati $d k k$., (2016) dimana pertumbuhan harian yang cukup baik untuk rumput laut adalah 2,03\% - 2,36\%. Sedangkan menurut Hernanto dkk., (2015) dalam usaha budidaya rumput laut laju pertumbuhan harian yang dikatakan baik dan menguntungkan yakni $2,36 \%$.

\section{Produksi Rumput Laut}

Produksi rumput laut adalah total perubahan biomassa populasi rumput laut yang dipelihara per satuan luas dalam siklus tertentu. Rata-rata hasil produksi $E$. denticulatum didapatkan pada long net yaitu sebesar 769,06 $\mathrm{g} / \mathrm{m}^{2}$ sedangkan pada alat wall net sebesar $643,44 \mathrm{~g} / \mathrm{m}^{2}$. Besaran produksi $E$. denticulatum yang dihasilkan dengan menggunaan long net tersebut signifikan lebih tinggi dibandingkan dengan besaran produksi E. denticulatum pada wall net. Produksi rumput laut yang dalam konteks penelitian merupakan fungsi dari pertumbuhan, maka perlakuan penelitian yang memiliki nilai LPS yang tinggi akan memberikan tingkat produksi yang lebih tinggi pula atau sebaliknya. Hal ini didukung oleh pernyataan Failu et al. (2016), bahwa peningkatan produksi pada kegiatan budidaya rumput laut yang dihasilkan erat kaitannya dengan laju pertumbuhan dari rumput laut tersebut, dimana semakin rendah laju pertumbuhan yang dihasilkan maka produksi yang dihasilkan akan semakin rendah. 
Perbedaan hasil penelitian menyangkut produksi rumput laut $E$. denticulatum pada kedua long net dan wall net terletak pada fungsi keterlindungan yang dapat diberikan oleh kedua alat tersebut. Alat wall net yang kurang optimal dalam memberikan perlindungan terhadap gangguan hama dan pengaruh gesekan dalam medium akibat goyangan berlebih tentunya memberikan fungsi dalam produksi rumput laut yang lebih rendah dibanding long net. Hal ini dikarenakan pada wall net didapatkan adanya ujung-ujung talus yang rusak dan patah diduga akibat serangan predator seperti ikan dan cuaca yang berubahubah. Menurut Citra (2014), menyatakan bahwa kurang berkembangnya kegiatan budidaya disuatu daerah diduga banyaknya masalah yang sering dihadapi oleh petani. Masalah tersebut, yakni adanya predator jenis ikan baronang (Siganus spp) yang sering mematahkan atau memakan thallus dari rumput laut pada saat dilakukan pemeliharaan. Kemudian diperkuat oleh pernyataan McHugh (2006); Kasim (2019), menjelaskan saat ini telah terjadi penurunan kualitas rumput laut setelah 20 tahun masa produksi rumput laut diwilayah Pasifik. Khusus untuk wilayah Indonesia, rendahnya produksi hasil budidaya rumput laut disebabkan oleh rendahnya kualitas bibit, metode budidaya yang kurang baik, intensitas penyerangan hama dan penyakit, efek lingkungan laut yang merupakan dampak dari perubahan iklim dunia.

Kehadiran banyaknya ikan herbivora di areal budidaya $E$. denticulatum dapat menimbulkan dampak negatif yang parah. Cara terbaik untuk mengatasinya adalah dengan menggunakan metode yang dapat melindungi E. denticulatum terhadap populasi ikan herbivora yang ada. Metode keramba jaring apung saat ini merupakan solusi terbaik untuk menghindari penggembalaan dan dengan demikian meningkatkan produksi (Kasim $d k k$., 2017). Menurut hasil penelitian Susilowati (2012) menyatakan bahwa hama pada saat kegiatan penelitian didominasi oleh hama yang menempel pada rumput laut, contohnya ikan baronang (Siganus sp) yang masih berukuran kecil. Hama ini menyerang pada bagian thallus dan memakan thallus yang mengakibatkan thallus rusak dan kemudian patah. Hal ini dapat ditanggulangi dengan pemakaian jaring untuk pengamanan rumput laut $E$. cottonii. Beberapa negara seperti Filipina dan Brazil telah mulai mengadakan upaya pemeliharaan yang dapat melindungi rumput laut dari serangan hama dengan menggunakan jaring walau masih sangat tradisional (Reis $d k k$., 2015, Dawes $d k k$., 1994, Tomas dkk., 2011).

\section{Parameter Kualitas Air}

Selama penelitian salah satu parameter yang diukur yaitu suhu. Kisaran suhu selama penelitian yaitu $28-30^{\circ} \mathrm{C}$. Kisaran tersebut masih dapat dikatakan baik untuk pertumbuhan $E$. denticulatum. Hal ini sesuai dengan hasil penelitian Gundo (2011), bahwa kisaran suhu yang dibutuhkan E. spinosum agar dapat tumbuh dengan baik yaitu $28-31^{\circ} \mathrm{C}$.

Setiap organisme laut memiliki kisaran toleransi yang berbeda-beda terhadap salinitas termasuk E.spinosum, Hasil pengukuran salinitas selama 42 hari di Perairan Pantai Lakeba diperoleh kisaran salinitas antara 34-35 ppt, salinitas yang terukur selama penelitian masih dikatakan cukup baik untuk pertumbuhan rumput laut. Hal ini didukung oleh pernyataan Kordi (2010) ; Pongarrang (2013), menyatakan bahwa kualitas air yang cocok untuk Eucheuma adalah salinitas 29-34 ppt. Menurut Anggadiredja., $d k k$ (2006) ; Bolqiah (2018), juga menyatakan bahwa kesuburan rumput laut juga dipengaruhi oleh salinitas,kisaran salinitas yang layak bagi pertumbuhan rumput laut adalah 33-35 ppt.

Kedalaman menjadi faktor penentuan lokasi budidaya rumput laut karena kedalaman berhubungan dengan daya tembus sinar matahari yang berpengaruh penting pada pertumbuhan. Hasil pengukuran kedalaman pada lokasi penelitian berkisar antara 2-7 $\mathrm{m}$. Berdasarkan nilai dari hasil tersebut kedalaman masih dikatakan baik untuk pertumbuhan rumput laut. Hal ini sesuai dengan pernyataan Akib (2015), bahwa lokasi budidaya pada kedalaman 6,5 m sampai 11,5 m menunjukkan nilai yang sesuai untuk dilakukannya budidaya rumput laut. Poncomulyo dkk., (2006) ; Risnawati (2018), menyatakan ketika air pada lokasi budidaya mengalami surut terendah sehingga pada rumput laut yang masih dapat tumbuh dengan baik pada kedalaman berkisar antara4-17 m.

Kecerahan perairan laut terkait erat dengan sejauh mana penetrasi cahaya matahari dapat masuk ke perairan yang dibutuhkan untuk prosesfotosintesis. Dari hasil pengukuran selama penelitian diperoleh nilai kecerahan 
$100 \%$ pada kedalaman $2 \mathrm{~m}$ pada saat surut terendah, dan kecerahan $100 \%$ pada kedalaman $7 \mathrm{~m}$ pada saat pasang tertinggi. Kecerahan tersebut masuk dalam kategori sangat baik untuk pertumbuhan rumput laut. Hal ini didukung oleh pernyataan Yusup (2017), bahwa nilai kecerahan $85 \%$ pada kedalaman 7 $\mathrm{m}$ pada saat surut terendah, dan kecerahan $85 \%$ pada kedalaman $10 \mathrm{~m}$ pada saat pasang tertinggi dikategorikan sangat baik untuk pertumbuhan rumput laut.

Arus berperan penting dalam pertumbuhan rumput laut, karena arus membawa zat hara yang sangat dibutuhkan thallus untuk tumbuh. Kecepatan arus yang diukur selama penelitian bekisar antara 0,119$0,222 \mathrm{~m} / \mathrm{s}$, kisaran tersebut masih dapat ditolerir oleh pertumbuhan E. spinosum. Hal ini sesuai dengan pernyataan Dubost et al., (1996) ; Kasim (2017), bahwa kecepatan arus air yang ideal untuk pertumbuhan makroalga adalah sekitar $0,10-0,50 \mathrm{~m} / \mathrm{s}$.

Derajat keasaman atau $\mathrm{pH}$ mempengaruhi pertumbuhan rumput laut. Hasil pengukuran $\mathrm{pH}$ selama penelitian yaitu 7,307,81 ppt. Kisaran nilai $\mathrm{pH}$ pada penelitian ini masih dalam batas aman untuk $\mathrm{pH}$ suatu perairan. Hal ini sesuai dengan pernyataan Anton (2017), bahwa kisaran pH 7,5-8 ppt masih dinyatakan layak bagi pertumbuhan Eucheuma sp. Kemudian Dawson (1986); Ridha (2016), menjelaskan bahwa kisaran nilai $\mathrm{pH}$ dalam suatu perairan untuk pertumbuhan makroalga adalah berkisar 7,75-8,26.

Selama penelitian nitrat berkisar antara 0,045-0,09 mg/1, nilai ini masih dapat ditolerir untuk mendukung pertumbuhan rumput laut. Hal ini sesuai dengan pernyataan Efendi (2002); Bolqiah (2018), yang menyatakan bahwa kadar nitrat yang dapat ditolerir oleh rumput laut adalah berkisar 0,001-0.002 mg/1.

Tinggi rendahnya kadar fosfat di suatu perairan adalah salah satu indikator untuk menentukan kesuburan suatu perairan. Kandungan fosfat selama penelitian berkisar antara 0,02-0,04 mg/l. Hal ini sesuai dengan pernyataan Blink (2004) ; Hilmi (2013), bahwa kandungan phosphat di perairan yang baik untuk pertumbuhan Eucheuma spinosum berkisar antara 0,032 -0,096 $\mu \mathrm{g} / \mathrm{l}$. Jika dalam perairan budidaya kandungan fosfat minimal 0,01 ppm, laju pertumbuhan biota tidak mengalami hambatan namun jika kadar fosfat turun dibawah kadar kritis tersebut maka laju pertumbuhan sel akan terganggu. Fosfat merupakan unsur yang esensial bagitumbuhan dan alga akuatik serta sangat mempengaruhi tingkat produktifitas perairan (Armita, 2011).

Hubungan laju pertumbuhan spesifik $E$. denticulatum dengan parameter kualitas air

Hasil model persamaan regresi berganda pertumbuhan rumput laut E. denticulatum pada long net dan wall net dengan parameter suhu (X1) berpengaruh signifikan dengan derajat hubungan negatif atau berbanding terbalik. Hal ini menunjukan bahwa semakin rendah nilai suhu maka laju pertumbuhan E. denticulatum yang dipelihara akan semakin meningkat, demikian sebaliknya. Bila nilai parameter suhu perairan selama pengukuran penelitian berkisar $28-30^{\circ} \mathrm{C}$, maka pada suhu $28^{\circ} \mathrm{C}$ lebih mendukung LPS $E$. denticulatum dibanding suhu $30^{\circ} \mathrm{C}$, demikian hal sebaliknya. Hasil hubungan ini sejalan dengan Dahuri (2001); Ichsan (2016) yang menyatakan bahwa suhu optimum perairan berkisar $26^{\circ} \mathrm{C}-29^{\circ} \mathrm{C}$ sehingga suhu memberikan kualitas air yang baik terhadap pertumbuhan rumput laut.

Peranan parameter kecepatan arus dalam hubungannya dengan LPS $E$. denticulatum yang dipelihara dalam longnet dan wallnet, walaupun berpengaruh signifikan namun pada kedua alat tersebut memiliki arah hubungan yang berbeda. Hubungan arah positif terjadi pada long net sementara hubungan arah negatif terjadi pada wall net. Hubungan arah positif menunjukan bahwa semakin tinggi nilai kecepatan arus maka pertumbuhan rumput laut akan semakin tinggi pula, demikian sebaliknya pada wall net. Kisaran kecepatan arus selama penelitian berkisar antara 0,119-0,222 m/s atau 11,9-22,2 cm/s. Kisaran tersebut lebih rendah dari pernyataan Hilmi (2013), bahwa kecepatan arus berkisar antara $0,2-0,4 \mathrm{~m} / \mathrm{s}$ dengan ratarata $0,3 \mathrm{~m} / \mathrm{s}$, kisaran tersebut baik untuk budidaya Eucheuma spinosum. Sedangkan pada wall net berpengaruh signifikan dengan derajat hubungan negativ atau tidak searah, artinya semakin rendah kecepatan arus maka pertumbuhan rumput laut semakin meningkat. Hal ini dikarenakan pemeliharaan pada wall net tidak terlindungi dari pengaruh fisik perairan seperti gelombang yang mengakibatkan patahan pada talus ruput laut, sehingga mepengaruhi pertumbuhan rumput laut. Pergerakan arus pada perairan akan mempengaruhi ketersediaan nutrien bagi 
pertumbuhan rumput laut. Hal ini sesuai dengan pernyataan Serdiati (2010), bahwa kecepatan arus juga sangat berperan untuk membawa nutrient / zat hara di perairan agar rumput laut dapat memperoleh zat hara dengan seoptimal mungkin untuk proses pertumbuhannya, selain itu pergerakan air juga dapat membersihkan rumput laut dari kotoran yang menempel sehingga tidak menghalangi proses fotosintesis.

Parameter kualitas air yang biasa juga mempengaruhi pertumbuhan rumput laut yaitu $\mathrm{pH}$, dimana $\mathrm{pH}$ menunjukkan sifat asam dan basa pada suatu perairan. Pengaruh $\mathrm{pH}$ terhadap pertumbuhan $E$. denticulatum pada long net dan wall net menghasilkan pengaruh yang signifikan. Arah hubungan yang bersifat positif mengindikasikan bahwa jika semakin tinggi kandungan $\mathrm{pH}$ pada suatu perairan Lakeba maka laju pertumbuhan $E$. denticulatum akan semakin meningkat pula. Nilai parameter $\mathrm{pH}$ perairan Lakeba selama penelititan berkisar 7,3-7,81. Arah hubungan positif tersebut mendukung Aslan (1991); Serdiati (2010) yang menyatakan bahwa rumput laut masih dapat tumbuh dan berkembang optimal pada kisaran pH 8-8,9.

Parameter nitrat dengan laju pertumbuhan spesifik pada kedua wadah pemeliharaan memberikan pengaruh yang signifikan dengan derajat hubungan positif atau searah. Hal ini menunjukkan bahwa semakin tinggi kandungan nitrat pada lokasi penelitian maka pertumbuhan rumput laut akan semakin meningkat. Adapun kisaran nitrat selama penelitian yaitu 0,045-0,09 $\mathrm{mg} / \mathrm{L}$ kisaran tersebut lebih rendah dan tidak sejalan dengan pernyataan Yusuf (2004) ; Bolqiah (2018) yang menyatakan bahwa kisaran nilai kandungan nitrat yang layak bagi kesuburan rumput laut ialah $0,1-3,5 \mathrm{mg} / \mathrm{L}$.

Fosfat merupakan bentuk fosfor yang dapat dimanfaatkan oleh rumput laut. Pada parameter fosfat dengan laju pertumbuhan spesifik yang dibudidaya pada long net berpengaruh signifikan dengan derajat hubungan negatif, sedangkan pada wall net menghasilkan derajat hubungan positif. Hasil pengukuran fosfat selama penelitian berada di kisaran 0,02-0,04 mg/l. Hasil arah hubungan negatif pada long net sejalan dengan Blink (2004) ; Hilmi (2013), bahwa kandungan phosphat di perairan yang baik untuk pertumbuhan Eucheuma spinosum berkisar antara $\quad 0,032 \quad-0,096 \mu g / 1$.Sungguh hal sebaliknya terjadi arah hubungan positif pada wall net, pengaruh signifikansinya dalam model hubungan sangat lemah. Konsentrasi fosfat dalam perairan merupakan unsur yang esensial terutama alga akuatik dan sangat mempengaruhi tingkat produktifitas perairan (Armita, 2011).

\section{KESIMPULAN}

Kesimpulan dari penelitian ini adalah: 1) Rata-rata laju pertumbuhan spesifik $E$. denticulatum yang dipelihara pada wadah alat longnet memiliki LPS yang lebih tinggi $(2,98 \%)$ dibandingkan dengan yang dipelihara pada wadah alat wallnet $(2,58 \%) ; 2$ ) Produksi rumput laut $\mathrm{E}$. denticulatum pada wallnet $\left(643,44\right.$ g. $\left.^{\mathrm{m}-2}\right)$ lebih rendah dibandingkan dengan longnet $\left(769,06\right.$ g.m $\left.{ }^{-2}\right)$; 3) Keterkaitan parameter fisika kimia Perairan Pantai Lakeba dengan LPS rumput laut Eucheuma denticulatum memiliki hubungan yang sangat kuat, baik rumput laut yan g dipelihara pada wadah longnet maupun wadah alat wallnet, yaitu, parameter suhu, kecepatan arus, $\mathrm{pH}$, konsentrasi nitrat, dan parameter konsentrasi fosfat.

\section{REFERENSI}

Abdan, A., Rahman, A \& Ruslaini. (2013). Pengaruh jarak tanam terhadap pertumbuhan dan kandungan karagenan rumput laut (Eucheuma spinosum) menggunakan metode long line. Jurnal Mina Laut Indonesia, Vol 3 (12): 113-123.

Akib, A., Magdalena, L., Ambeng \& Muhtadin, A. (2015). Kelayakan kualitas air untuk kawasan budidaya Eucheuma cottoni berdasarkan aspek fisika, kimia dan biologi di Kabupaten Kepulauan Selayar. Jurnal Pesisir dan Laut Tropis. Vol 1 (1) : 25-36.

Anton. (2017). Pertumbuhan dan kandungan karaginan rumput laut (eucheuma) pada spesies yang berbeda. Jurnal Airaha. Vol 5 (2): 102-109.

Ariyati, R. W., Widowati, L. L \& Rejeki. (2016). Performa produksi rumput laut euchema cottonii yang dibudidayakan menggunakan metode long-line, vertikal dan horisontal. Prosiding Seminar Nasional Tahunan Ke-V 
Media Akuatika : Jurnal Ilmiah Jurusan Budidaya Perairan. 2021. 6(4): 192-203.

Hasil-Hasil Penelitian Perikanan dan Kelautan.

Armita, D. (2011). Analisis Perbandingan Kualitas Air di Daerah Budidaya Rumput Laut Dengan Daerah Tidak ada Budidaya Rumput Laut, di Dusun Malelaya, Desa Punaga, Kecamatan Mangarabombang, Kabupaten Takalar. Program studi menejemen sumberdaya perairan. Jurusan ilmu kelautan Fakultas Ilmu Kelautan dan Perikanan. Universitas Hasanudin. Makassar.

Bolqiah, S. (2019). Hubungan Faktor Oseanografi Terhadap Pertumbuhan Rumput Laut Dengan Metode Rakit Jaring Apung Di Perairan Lakorua Kecamatan Mawasangka Tengah Kabupaten Buton Tengah. Jurnal Sapa Laut (Jurnal Ilmu Kelautan), 3(1), 2536.

Citra A. M., Tassaka A. R., Latama G \& Rustam. (2014). Pengaruh perbedaan varietas rumput laut (Kappaphycus sp) dan variasi kedalaman terhadap pertumbuhan dan produksi rumput laut menggunakan metode budidaya "top down". Jurnal Ilmu Kelautan dan Perikanan.Vol 24 (1):. ISSN: 08534489.

Dawes, C. J., Lluisma, A. O., \& Trono, G. C. (1994). Laboratory and field growth studies of commercial strains of Eucheuma denticulatum and Kappaphycus alvarezii in the Philippines. Journal of Applied Phycology, 6(1), 21-24.

Gundo, C., Soemarrno \& Diana, A. (2011). Analisis parameter oseanografi di lokasi pengembangan Eucheuma spinosum pulau nain kabupaten minahasa utara. Ilmu Kelautan. Vol. 16 (4) : 193-198. ISSN 0853-7291.

Hernanto, A. D., Rejeki, S \& Ariyati, R. W. (2015). Pertumbuhan budidaya rumput laut Eucheuma cottonii dan gracilaria $s p$. dengan metode long-line di Perairan Pantai Bulu Jepara. Jurnal Pengelolaan dan Teknologi Akuakultur 4 (2): 60-66.

Hilmi, Y. F., Nunik, C \& Nihla, F. (2013). Pengaruh kedalaman tanam terhadap pertumbuhan Eucheuma spinosum pada budidaya dengan metode rawai. Jurnal Kelautan. Vol 6 (1) : 75-86.
Ichsan, N. A., Husain, S \& Patang. 2016. Pengaruh kualitas air terhadap produksi rumput laut (Kappaphycus alvarezii). Jurnal Pendidikan Teknologi Pertanian. Vol 2 : 27-40.

Insan, A. I., Widyartini, D. S., \& Sarwanto, S. (2013). Posisi tanam rumput laut dengan modifikasi sistem jaring terhadap pertumbuhan dan produksi Eucheuma cottonii di perairan Pantura Brebes. Jurnal Litbang Provinsi Jawa Tengah, 11(1), 125-133.

Kasim, M., Balubi AM., Mustafa A, Muzuni \& Jalil W. (2019). Penerapan kurungan apung horisontal dalam budidaya rumput laut jenis Kappahycus alvarezii dan Eucheuma denticulatum. Jurnal Sains dan Inovasi Perikanan. 3(2), 4551.

Kasim, M., Mustafa, A., Male, I., Muzuni, W. Jalil. (2017). New methods on cultivation of Eucheuma denticulatum and Kappahycus alvarezii in Indonesia. Journal of Fisheries and Aquatic Science. 12(5), 207-217.

Kasim, M., Mustafa, A, \& Munir, T. (2016). The growth rate of seaweed (Eucheuma denticulatum) cultivated in longline and floating cage. AACL Bioflux. 9(2), 291-299.

Kasman, Rahman, A. \& Ruslaini. (2016). Pengaruh jarak antar tali gantung vertikultur terhadap kestabilan tali bentang vertikultur rumput laut (Kappaphycus alvarezii) dengan metode bentuk segi tiga terbalik seri. Media Akuatika. 1(1), 27-36.

Komang, I. D., Wayan, I. A. \& Ni, M. E. (2017). The utilization of halymenia durvillaei to support the management of Eucheuma spinosum seaweed farming in Geger coastal area, Bali. Jurnal Metamorfosa. 4(1), 65-71.

Lakhsmi, L. W., Rahayu, S., Tristiana, Y. \& Restiana, W. A. (2015). Efisiensi produksi rumput laut $E$. cotonii dengan metode budidaya long line vertikal sebagai alternatif pemanfaatan kolom air. 11(1), 47-56.

Luhan, M. R. J. \& Sollesta. (2010). Growing the reproductive cells (carpospores) of the seaweed, kappaphycus striatum, in the laboratory until outplaning in the 
Media Akuatika : Jurnal Ilmiah Jurusan Budidaya Perairan. 2021. 6(4): 192-203.

field and naturation to tetrasporophte. $J$ Appl Phycol 22, 579-585.

Musa, N. \& Wei, L. S. (2008). Bacteria attached on cultured seaweed gracilaria changii at Mangabang Telipot, Terengganu. Academic Journal of PlantSciences. 1(1), 01-04.

Parenrengi, A., Mat, F., Makmur, Sri R. H. M. (2016). Seleksi rumput laut Kappaphycus striatum dalam upaya peningkatan laju pertumbuhan bibit untuk budidaya. Jurnal Riset Akuakultur. Vol. 11 (3) : 235-248. ISSN : 2502-6534

Pongarrang, D., Rahman, A \& Iba, W. (2013). Pengaruh jarak tanam dan bobot bibit terhadap pertumbuhan rumput laut (Kappaphycus alvarezii) menggunakan metode vertikultur. Jurnal Mina Laut Indonesia. 3(12), 94-112.

Pongmasak, P. R., Tjaronge, M \& Madeali, M. M. (2009). Musim tanam rumput laut di perairan Tonra, Kabupaten Bone, pantai Timur Sulawesi Selatan. In Sudradjat A, Supriyadi H, Hanafi A, Kristanto AH, Chumaidi, Mustafa A, Imron \& Insan I. (Eds.). Prosiding Forum Inovasi Teknologi Akuakultur 2009. Pusat Riset Perikanan Budidaya. Jakarta. hlm. 413-421.

Reis, R. P., Pereira, R.R \& de Góes, H. G. (2015). The effi ciency of tubular netting method of cultivation for Kappaphycus alvarezii (Rhodophyta, Gigartinales) on the southeastern Brazilian coast. $J$ Appl Phycol. 27, 421 $-426$.

Ridha, M. J, Kasim, M., Nur, I. (2016). Keberadaan thalus rumput laut Eucheuma spinosum sebagai media penempelan macroalga di Perairan Pantai Lakeba Kota Baubau. Jurnal Manajemen Sumber Daya Perairan. 1(3), 333-338.

Risnawati, Kasim, M. \& Haslianti. (2018). Studi kualitas air kaitanya dengan pertumbuhan rumput laut (Kappaphycus alvarezii) pada rakit jaring apung di Perairan Pantai Lakeba Kota Bau-Bau Sulawesi Tenggara. Jurnal Manajemen Sumber Daya Perairan. 4(2), 155-164.

Susilowati, T., Rejeki, Dewi, N \& Zulfitriani. (2012). Pengaruh kedalaman terhadap pertumbuhan rumput laut (Eucheuma cottonii) yang dibudidayakan dengan metode longline di Pantai Mlonggo, Kabupaten Jepara. Jurnal Saintek Perikanan. 8(1), 7-12.

Suyono. (2012). Analisis Regresi untuk Penelitian. Penerbit CV. Budi Utama. Yogyakata.

Tassakka, A. C. M. A., Latama, G., \& Rustam, R. (2014). Pengaruh Perbedaan Varietas Rumput Laut (Kappaphycus sp) dan Variasi Kedalaman Terhadap Pertumbuhan dan Produksi Rumput Laut Menggunakan Metode Budidaya "Top Down". Torani Journal of Fisheries and Marine Science, 24(1). 15-23.

Yusup, S., Kasim, M \& Balubi A. M. (2017). Pengaruh bobot awal yang berbeda terhadap pertumbuhan dan kandungan karagenan rumput laut Kappaphycus alvarezii yang terserang epifit dalam rakit jaring apung. Media Akuatika. 2(4), 509-518. 